\title{
The Asian Recession and Northern Labour Markets
}

\author{
Yongzheng Yang \\ National Centre for Development Studies \\ Australian National University \\ ACT 0200, Australia \\ Email: yongzheng.yang@anu.edu.au \\ Phone: 61-2-6249 0431 \\ Rod Tyers \\ Faculty of Economics and Commerce \\ Australian National University \\ ACT 0200, Australia \\ Email: rod.tyers@anu.edu.au \\ Phone: 61-2-6249 3364
}

WORKING PAPERS IN ECONOMICS AND ECONOMETRICS No. 372

Faculty of Economics and Commerce

and

Economics Program, Research School of Social Sciences

Australian National University

Revised July 1999

National Library of Australia Card Number

And ISBN number 086313726 


\title{
The Asian Recession and Northern Labour Markets
}

\begin{abstract}
One of the real effects of the recession in East and Southeast Asia has been a contraction in domestic demand that exceeds the corresponding contraction in output. The volume of Asian net exports of manufactures to the north has therefore risen. This "trade composition" effect disadvantages comparatively labour intensive northern manufacturing and hence northern workers. There is, however, also a substantial "capital account" effect that has raised investment in the north and thereby aggregate demand. This paper examines the magnitudes of these two effects in a broader analysis of the real impacts of the Asian recession that is grounded in a global general equilibrium framework. Northern workers are found to be net beneficiaries in the short and medium run.
\end{abstract}

\section{Introduction}

Widening wage differentials in the United States and increasing unemployment in Europe have attracted intense interest in the 1990s. ${ }^{1}$ The thrust of this new literature has been to seek explanations for the poor labour market performance by low skill workers observed in most of the industrialised world. Workplace automation, or "skill-upgrading", is most commonly seen as the generic factor influencing labour market change throughout the "north". Nonetheless, it is widely conceded that at least part of the decline in the performance of northern low skill workers has been attributable to the freer trade, particularly with developing countries and, most particularly, with Asia.

As technical progress in communications and transport have made capital and skill progressively more mobile internationally, governments around the world have sought a more general liberalisation of their economies to attract these mobile resources. Such reforms have also taken place in the south, and particularly in rapidly developing Asia. There, however, relative capital scarcity, combined with high savings rates and perceived high rates of return on investment, saw an extraordinary rate of capital accumulation. ${ }^{2}$ In 1997, however, this process stalled due to what has been called the "Asian financial crisis". Several of the

\footnotetext{
${ }^{1}$ Several surveys of this recent research are available, including those by Bhagwati and Kosters (1994), Wood (1994), Cooper (1994), Burtless (1995), Freeman (1995), Richardson (1995) and Tyers et al. (1999a).

${ }^{2}$ A transformation of more modest overall economic impact is currently taking place due to reforms in the former centrally planned economies. This change will prove comparatively important in Europe but it is not addressed in this paper.
} 
developing economies that had earlier been major contributors to Asian growth slid into deep recession. ${ }^{3}$.

Our interest is in the labour market implications of this regional recession, particularly for Asia's trading partners in the north. We make no attempt to simulate the short run dynamics of the crisis. Instead, we emphasise the real effects of the crisis and address what can be said about their northern implications using comparative statics. Two sets of real shocks form our starting point. First, there was a severe contraction of domestic investment (as home savings fled abroad and foreign savings in Asia were withdrawn). ${ }^{4}$ We think of this as the "capital account" effect, seen to raise aggregate demand in the north. Second, as Asian wealth fell there was a severe contraction in domestic demand. This contraction was greater in magnitude than the corresponding one in Asian output and hence, while Asian imports fell, (mainly manufactured) Asian exports expanded. We think of this as a "trade composition" effect. Understanding this effect is complicated, however, by widespread temporary unemployment of Asian capital as heavily indebted firms foundered following large nominal depreciations and the credit crunch that followed. ${ }^{5}$ Recent evidence suggests that a considerable number of firms in the most affected countries were rendered insolvent, and a larger number illiquid. ${ }^{6}$ These firms either closed their doors or contracted their output pending the resolution of property rights as between owners and creditors. In estimating the effects of the recession on the north, particularly in the medium run when this capital will be back on line, it is important that such changes in production are characterised explicitly, rather than subsumed in a generic "productivity shock".

A number of studies of the northern impacts of the preceding Asian "long boom" employed comparative static global general equilibrium analysis, ${ }^{7}$ and there are some similar studies of the Asian recession. ${ }^{8}$ A growing number have used fully dynamic models, some with financial markets represented. ${ }^{9}$ The behaviour that precipitated the crisis in Asia is still

\footnotetext{
${ }^{3}$ See Corsetti et al. (1998), McLeod and Garnaut (1998), Goldstein (1998), Radelet and Sachs (1998) and Wong (1998).

${ }^{4}$ The magnitudes of capital account changes are documented carefully by Makin (1999).

${ }^{5}$ These related impacts are foreshadowed in the early analysis by Corbett and Vines (1999a and b).

${ }^{6}$ See Suryahadi (1998) for evidence on the Indonesian case and, for a comprehensive review, World Bank (1999).

${ }^{7}$ See Burfisher et al. (1994), Krugman (1995), Minford et al. (1997) and Tyers and Yang (1997 and 1999a).

${ }^{8}$ See, for example, Adams (1998), Noland et al. (1998) and Suryahadi (1998).

${ }^{9}$ Although the events that precipitated the crisis are now better understood, the best dynamic global macroeconomic models to date still retain fully informed risk neutral financial agents with perfect foresight, or model-consistent expectations, and so cannot fully endogenise the capital flight of 1997 . They do, however,
} 
not fully represented in such models, however, and the associated studies tend to emphasise implications for prudential regulation and macroeconomic policy rather than real effects outside the region. In examining these real effects, comparative static analysis allows us the luxury of more detailed microeconomics and greater disaggregation than is available in most fully dynamic models. To achieve this we modify an established global general equilibrium model for the analysis of very short run behaviours of the type exhibited during the Asian recession and to improve its representation of labour market behaviour. We employ the full Version 4 GTAP database to distinguish the markets for both skilled and unskilled labour and we construct two alternative labour demand systems. ${ }^{10}$ The model is then used to examine both the short run implications of the Asian recession and those appearing in medium run in which property rights issues are resolved and Asian capital is no longer unemployed. This medium run gives rise to what is sometimes referred to as the export recovery phase. Further, since the preceding long Asian boom and the Asian recession (or at least Asia's recovery from that shock), are qualitatively different, we offer some comparisons of the labour market implications of each.

In Section 2 a brief review of the Asian recession is offered and our choice of model explained. Section 3 then provides a summary of the structure and behaviour of the model. Our construction of experiments with it is detailed in Section 4 and the results summarised in Section 5. Section 6 then offers conclusions.

\section{The Asian recession}

The events of 1997 are already well documented in a number of studies. ${ }^{11}$ Our interest is in the associated real shocks and their implications for labour markets. We include Japan in our analysis despite important differences in the character of its recession from those elsewhere in developing Asia. ${ }^{12}$ The bursting of the 1980s asset bubble there caused a decline in investment that accelerated in 1997 in spite of a macroeconomic policy that maintained very low short-term interest rates. Private consumption in Japan remained comparatively stable during the 1990s but it declined in the crisis period. The associated rise in savings combined with the decline in investment to further expand Japan's current account surplus. In addition,

precipitate valuable insights into the onset and management of such recessions. See, for example, McKibbin (1998a and b) and McKibbin and Martin (1998).

${ }^{10}$ The GTAP database is a product of the Global Trade Analysis Project. See McDougall et al. (1998).

${ }^{11}$ See IMF $(1998,1999)$ and the publications cited in footnote 3. 
a trend toward lower working hours, combined with the recent implementation of a standard 40-hour week caused a decline in total labour hours and an associated reduction in output per worker. ${ }^{13}$ Thus, Japan's trade surplus rose while its GDP fell. ${ }^{14}$

In the most affected countries of developing Asia the scale of the contractions was proportionally larger. ${ }^{15}$ Worst hit have been Indonesia and Thailand but the economies of Malaysia and Korea also contracted substantially. The crisis in these countries began in Thailand in mid-1997 following a period during which export performance had begun to falter and foreign currency denominated debt to accumulate. As doubts arose about the government's commitment to honour implicit guarantees to maintain the nominal exchange rate, a capital flight ensued resulting eventually in a very substantial currency depreciation. The sharp rise in domestic debt and debt service costs that followed precipitated the associated financial crisis. ${ }^{16}$ Fear of similar developments appears then to have been self-fulfilling in near neighbours Indonesia and Malaysia. As savings were withdrawn from these economies, and their currencies depreciated, asset prices fell and considerable wealth was lost. Private consumption fell and savings rose. Very large declines in domestic investment combined with the rise in savings to create substantial capital account deficits counterbalanced on the current account side by collapses in imports. Overall, one year after the onset of the crisis, export values had not begun to rise. ${ }^{17}$ Of course, considering the substantial currency depreciations these countries experienced, this does imply a rise in export volumes offset by a fall in US\$ export prices. ${ }^{18}$

The primary real shocks were as follows. First, as savings fled domestic investment declined. In Japan, where the process was more gradual, investment fell by about a tenth in the two years from late 1997. ${ }^{19}$ In the most affected economies of developing Asia, however,

\footnotetext{
12 The financial origins of the Japanese recession are discussed in Horiuchi (1998).

${ }^{13}$ See Bayoumi and Towe (1998).

${ }^{14}$ See IMF (1988), Chapter IV.

${ }^{15}$ Their contributions to global GDP are smaller in magnitude than that of Japan, however. The 1998 contraction of the Japanese economy by 2.8 per cent took US $\$ 114$ billion off global output. This compares with a total of US\$83 billion from the combined contractions in the affected developing Asian countries. Although PPP based comparisons would enhance the latter figure, they would not nullify the point of the comparison.

${ }^{16}$ A clear summary of these events is provided in the retrospective by Corbett and Vines (1999b).

${ }^{17}$ See IMF (1998) Table 2.6.

${ }^{18}$ Interestingly, however, since Japan has been an important destination for exports from developing Asia, holding the line on export values has meant a considerable redirection of exports toward the European Union and the United States.

${ }^{19}$ According to IMF(1998), Table 3, gross fixed capital formation in Japan declined by 3.5 per cent in 1997 and was forecast to decline by 7.2 per cent in 1998 .
} 
the initial panic of 1997 was so great that domestic investment declined by as much as half. Domestic capital goods and construction demand collapsed. The contractionary impact on output was further exacerbated by a collapse in private consumption, driven by the associated wealth effects of asset price declines. Imports therefore fell dramatically.

The second of the real shocks is a further short run decline in domestic production in the affected economies. In a financial crisis as deep as that in developing Asia, where the common credit squeeze was greatly exacerbated by an associated currency crisis and hence a blowing out of debt service costs, there is a high incidence of illiquidity and insolvency. ${ }^{20}$ This is the more so in developing Asia because of the rapid expansion of private sector credit there during the early 1990s. In the decade to 1995 , for example, private sector credit as a proportion of GDP tripled in Indonesia and doubled in Thailand. ${ }^{21}$ Equity markets were comparatively underdeveloped and investment during the period was financed primarily by debt. Debt-equity ratios of Korean domestic manufacturing firms in the mid 1990s, for example, were double those of manufacturing firms in the US. It is therefore inevitable that the substantial rise in debt service costs would drive more than the usual proportion of firms in the most affected economies into insolvency.

This is borne out in a recent World Bank survey of 3,700 companies in the worst affected economies. ${ }^{22}$ Fully 15 per cent of these companies reported insolvency. In Indonesia, the number rises to 51 per cent. In addition, across the five most affected economies, a larger 28 per cent of surveyed companies were thus far technically solvent but illiquid. In these, although post-crisis assets still exceed liabilities, debt service costs exceed operating surplus. These firms were in imminent danger of becoming insolvent. In the short run, with ownership issues unresolved, many insolvent and near-insolvent firms would have shut down pending resolution. At the very least, and particularly for small firms, the prospect of new management and the necessary commitment of all new operating surplus to creditors would have substantially reduced incentives to maintain production.

In summary, then, production declines in the affected Asian economies have two sources. First, there is the decline in investment and hence reduced demand for capital goods. This is associated with a retreat of savings abroad and a real depreciation. Private consumption falls as local wealth and purchasing power collapse. Normally, the real

\footnotetext{
${ }^{20}$ See the discussion of this in Corbett and Vines (1999a). This effect is also noted in Lane et al. (1999).

${ }^{21}$ See IMF (1998, Ch.3) Table 3.8.
} 
depreciation would be expected to ensure an offsetting surge in export demand. In the short run, however, this is restrained by the second cause of output contraction. The presence in developing Asia of considerable foreign denominated debt meant that the currency depreciations raised private debt service costs considerably. And this caused an extraordinary number of insolvencies and a high level of illiquidity amongst Asian firms. The resulting shutdowns left part of each affected industry's capital stock idle in the short run.

The analysis of these combined shocks requires a model capable of representing an open capital account in each region and in which exogenous shocks can be applied to the level of output by industry in a closure that permits the idling of industry-specific capital. The model we choose is discussed in Section 3, to follow.

\section{The Model}

We use an adaptation of the GTAP global general equilibrium model. ${ }^{23}$ Its analytics are summarised in Table 1. As a starting point, it offers the following useful generalisations: (i) a capital goods sector in each region to service investment, (ii) explicit savings, albeit at an exogenous rate, in each region combined with open regional capital accounts that permit savings in one region to finance investment in others, (iii) multiple trading regions, goods and primary factors, (iv) non-traded goods, (v) product differentiation by country of origin, (vi) empirically based differences in tastes and technology across regions, (vii) non-homothetic preferences, and (ix) explicit allowance for transportation costs and policy distortions. ${ }^{24}$

For the corresponding database, we use the GTAP Version 4 data, aggregated into the regions listed in Table 2. ${ }^{25}$ Note that we use the rather large aggregate, "developing Asia" to represent the affected region. Within this region there is considerable variance in the degree to which countries were affected by the recession. As discussed in Part I, Indonesia was worst affected while China has, to date, been relatively unscathed. The shocks affecting this region are therefore averages across the region and do not reflect the severity of the effects in such economies as Indonesia.

\footnotetext{
${ }^{22}$ The World Bank (1999) study is reported in Asiaweek, 16 April 1999.

${ }^{23}$ For a detailed description of the standard version of this model, see Hertel (1997).

${ }^{24}$ These generalisations mean that the conditions essential to factor price equalisation no longer exist and hence transmitted factor market effects are muted relative to simple Heckscher-Ohlin-Samuelson formulations. See Falvey et al. (1997), Francois and Nelson (1998) and Tyers (1999).

${ }^{25}$ For a detailed description of the database, see McDougall et al. (1998).
} 
To preserve the diversity of factor proportions across industries and so reflect trade effects of shocks as accurately as possible ${ }^{26}$, we use the full list of 50 sectors available in the database. Once each solution is complete, the results are aggregated for presentation to six sectors, as indicated in Table 2. This aggregation is based on factor proportions in the EU. ${ }^{27}$ When grouped in this way, the differences between the factor shares of each industry group are not stark, particularly in manufacturing and services, as indicated in Table 3. The relatively skill intensive industries, for example, tend also to have high labour and capital shares. Indeed, the starkness of the contrast between unskilled labour intensive manufacturing and skill intensive manufacturing is further reduced when the factor content of intermediate inputs is taken into account. Broadly, however, agriculture is labour intensive, mining capital intensive and manufacturing labour intensive. Typical of all the northern industrial economies, however, the dominant services sector is capital intensive relative to manufacturing and it comprises two subsectors, one of which is intensive in unskilled labour while the other combines relatively balanced shares of the three mobile factors.

Households and firms in the model consume a composite of goods and services that is a blend of home products and imports. The composition of this blend depends on relative prices and an elasticity of substitution. In turn, imports are a blend of the products of all regions and its composition depends on regional trading prices and a further elasticity of substitution. This structure facilitates the departures from the law of one price that tend to occur even in tradeable goods sectors in the short and medium run. ${ }^{28}$ For this reason, we do not adopt the common practice amongst GTAP users of choosing larger than the standard elasticities of substitution. The elasticities used are listed in Table 4. On the supply side, the derived demand for primary factors stems from a nest of constant elasticity of substitution (CES) functions. These are mapped out in Figure 1 and the associated substitution elasticities are listed in Table 4.

\footnotetext{
${ }^{26}$ The importance of accurately representing the diversity of factor proportions across industries is emphasised by Tyers (1999).

${ }^{27}$ The 50 industries are grouped in broad sectors then ranked according to their labour intensity on the one hand and their skill intensity on the other. If an industry ranks higher on labour intensity than it does on skill intensity it is placed in the labour intensive sector in Tables 2 and 3. If it ranks higher by the skill intensity criterion it is placed in the skill intensive subcategory, even though its skill share may be smaller than its labour share.

${ }^{28}$ The early literature on real exchange rate changes tended to focus on associated relative price changes where tradeable goods prices retained parity with international trading prices. More recently it has become certain that short run departures from the law of one price occur across all tradeable goods sectors. See Engel (1999).
} 
Our adaptation of the model's essential structure involves changes to its intermediate input and labour demand structure. We have modified the standard GTAP nested CES production structure, using instead that set out in Figure 1. In particular, we note that the standard GTAP formulation has intermediate goods and factors used in fixed proportions by volume in all industries. This restricts substitution by firms in the face of factor and product price changes, so we have made output a CES composite of intermediate products and primary factors. Second, to more accurately reflect factor market impacts of external shocks, we have recomposed the demand structure for unskilled labour, skilled labour and capital. This allows the two types of labour to be differently substitutable for each other by firms than each is substitutable for the other mobile factor, capital. ${ }^{29}$ And third, households are permitted some scope to substitute between the types of labour supplied. ${ }^{30}$

In addition, the short run effects of the Asian recession on production require a closure that makes capital industry specific and production levels in affected economies exogenous while industry level capital utilisation rates become endogenous. Modifications to the code were made to facilitate these changes. And finally, we craft capital account closures that are consistent with the objectives of each experiment with the model. These are spelled out in association with the shocks themselves in Section 4, to follow.

\footnotetext{
${ }^{29}$ Hamermesh's (1993, Ch.3 part IV) survey of the evidence on skill-capital complementarity suggests only weak evidence for it. We have therefore chosen to omit such behaviour in this formulation. His corresponding surveys of estimates of substitutability between capital and generic labour on the one hand and skilled and unskilled labour on the other imply only weak evidence of any consistent departure from unit elasticities of substitution. In subsequent work (Tyers and Yang, 1999b), we investigate capital accumulation and associated technical change, experimenting with two alternative nested CES structures that differ in the extent of capitalskill complementarity.

${ }^{30}$ In experiments discussed in this paper, the potential for households to transform labour is rendered negligible.
} 


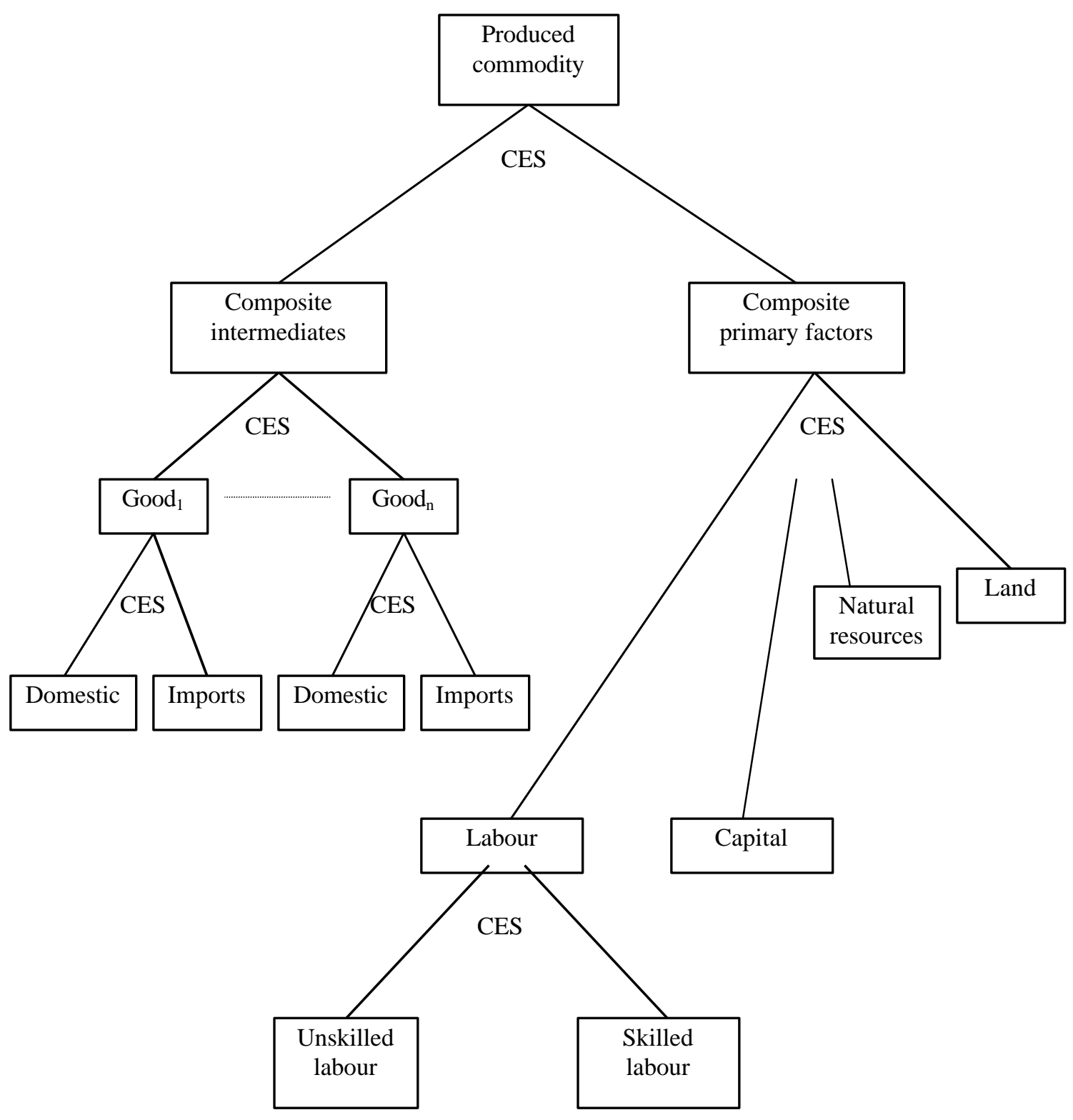

Figure 1

\section{The Construction of Asian Recession Shocks}

Both short and medium run consequences are examined. Throughout, we use a version of the model that has no intersectoral mobility of capital. Returns to capital therefore vary across industries. In the short run, as discussed in Section 2, the set of real shocks comprises changes in the international distribution of investment, changes in saving rates and therefore changes in trade balances. Indeed, since the short run effects on both investment 
levels and current account deficits are known, we set these as exogenous, rendering the rate of savings in developing Asia and Japan endogenous to maintain the balance of payments. Rates of savings in the other regions remain exogenous, however, wile the other elements of their capital and current accounts are endogenous. In addition, where insolvencies and illiquidity have resulted in plant closures or slow-downs that have reduced observed output in developing Asia and Japan by more than would have occurred following the declines in investment there, production levels are made exogenous. In sectors where this occurs, capital is left unemployed. Labour markets in these affected regions are assumed to remain flexible and both skilled and unskilled labour to remain mobile between industries. Finally, to reflect the anecdotal evidence of a substantial retreat by workers to agriculture in developing Asia, labour productivity there is reduced and land productivity raised. The complete set of shocks and the closures adopted in the short run case are detailed in Table $5 .^{31}$

In the medium run, we assume that debt workouts have resolved property rights issues and that capital is no longer unemployed in developing Asia and Japan. Output in each sector is no longer exogenous. Capital remains immobile between industries, however. As capital utilisation rates return to benchmark levels, the retreat of labour to agriculture is reversed and factor productivity in agriculture returns to its reference levels. Investment is assumed to have contracted by the same proportion as in the short run and the average savings rate is now rendered exogenous at its heightened short run level. The trade balance is therefore restored to endogeneity. This allows any recovery in national incomes in the two affected regions to further raise total savings and hence for the trade imbalance to widen further as growth in exports leads their recoveries. ${ }^{32}$ The shocks and closures adopted in this medium run scenario are detailed in Table 6.

Returning to the short run, our treatment of capital unemployment deserves further explanation. Given that capital is industry specific and that data are already available on the extent of short run output contractions, we can make output in each industry exogenous and reduce it to a known extent, setting industry level capital use as endogenous. How precisely

\footnotetext{
${ }^{31}$ The magnitudes of the output contractions imposed in the short run in developing Asia and Japan appear later, in Table 8.

${ }^{32}$ Although there is evidence that investment has begun to rise again in developing Asia, the effect this might have had in reducing the capital account deficit there is probably balanced by savings changes that support a rise in debt service flows on the current account. Since our model allows no interregional factor ownership, there are no interregional flows of capital returns. For this reason, we maintain the same investment levels and savings rates as in the short run.
} 
does such an imposed reduction in output at the industry level bring about a reduction in capital use in the model and on what does the extent of this reduction depend? ${ }^{33}$ As indicated in Section 3, the production structure is nested CES. To illustrate the behaviour involved, consider a single industry employing just labour, $L$, and capital, $K$, which it combines according to the CES production function:

$$
y=\left[\alpha L^{-\rho}+\beta K^{-\rho}\right]^{-\frac{1}{\rho}}
$$

In the short run $K$ is industry specific and its rate of return, $r$, is endogenous to the industry. Labour is mobile, however, and its wage, $w$, is determined in the wider economy, as is the industry's product price, $p$. The industry comprises firms that are price taking in both product and factor markets and, as do all industries in the model, it makes zero collective profits. The industry can therefore be thought of as a single firm that always produces at its minimum efficient scale. For our purpose here it is sufficient to locate minimum efficient scale (MES) for a tractable case. Set the elasticity of substitution to $\sigma=1 /(1+\rho)=1 / 2$ and hence $\rho=1$. And simplify further by setting $\alpha=\beta=1$. Short run average cost is then minimised at

$$
y_{M E S}=\frac{K}{\left[1+\left(\frac{w}{r}\right)^{1 / 2}\right]}
$$

At this output, short run marginal cost and short run average cost are equal at:

$$
S M C=\operatorname{Min}\{S A C\}=p=\left[w^{1 / 2}+r^{1 / 2}\right]^{2}
$$

Since the product price and the wage are determined in the wider economy, we can think of them as given. The above condition then fixes the rate of return on capital in the focus industry, irrespective of the quantity employed. Only one rate of return is consistent with zero profit, price-taking behaviour no matter what the level of output or capital use in the industry. Once the rate of return on the industry's capital is known, there remains a one to one relationship between output, $y_{M E S}$, and capital use, $K$. If output is reduced because some firms

\footnotetext{
${ }^{33}$ At first, for example, it might be expected that capital used at the industry level cannot be fixed without first fixing the rate of return on capital in each industry. This proves not to be the case provided the remaining operational firms are price takers earning zero pure profits.
} 
shut down, so long as the remaining firms behave perfectly competitively, the quantity of capital that is still in production is clear. ${ }^{34}$

It is useful to know, however, what the effect of the factor substitution elasticity is on the extent of capital unemployment. This can be seen from Figure 2. There the exogenous production reduction is from $y_{0}$ to $y_{1}$. Were the technology to be Leontief the quantity of capital employed would decline equiproportionally (from $K_{0}$ to $K_{l}$ in the figure). This is true even if factor substitution is elastic, so long as the product price and the wage remain unchanged. For a constant wage, however, if there is a rise in the

Figure 2

\section{Capital use reductions implied by a given output contraction}

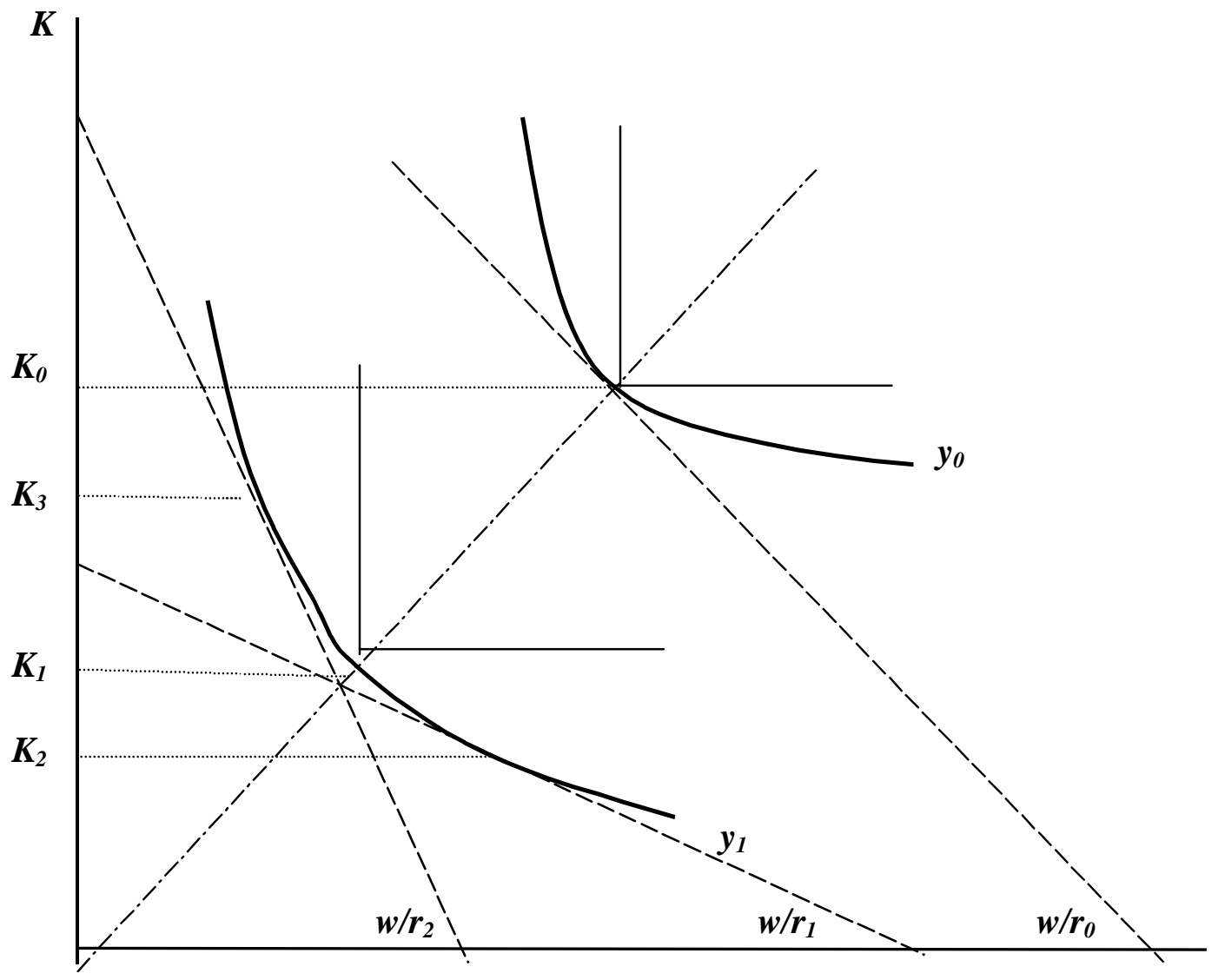

$L$

\footnotetext{
${ }^{34}$ If the extent of the shutdowns is sufficient, in spite of the general recession, to drive the industry's product price up, then the rate of return on the industry's capital must rise and the owners of capital still in production will earn rents.
} 
product price there will be a rise in the return on the industry's capital. This will result in a larger decline in capital use the more elastic is the substitution between capital and labour (say to $K_{2}$ in the figure). If, on the other hand, the product price should fall the decline in capital use will be smaller the greater is the factor substitution elasticity (say to $K_{3}$ in the figure). These two results also apply if the product price is unchanged and there is a fall (rise) in the wage.

\section{The Results}

First consider the short run shocks detailed in Table 5. Particularly important among these are the global redistribution of investment and the changes in savings rates. The corresponding (simulated) changes in the balance of payments in each region are displayed in Table 7. As foreshadowed, investment falls and savings rise in Asia and these changes are balanced by substantial declines in imports and rises in exports. The allocation of investment across other regions is endogenous in the model and differences in the accessibility of domestic capital markets across regions are not represented, nor are the short run effects of macroeconomic policy responses in the north. ${ }^{35}$ As it turns out, the rise in investment is most substantial in Europe and, therefore, so also is the rise in European imports and the European real appreciation relative to developing Asia.

Nonetheless, all the other non-Asian regions experience enlarged investment with (fixed rate) savings rising slightly with national income in each case. The substantial shifts in their capital accounts toward surplus are then matched by shifts in their current accounts toward deficit which take the form of very substantial rises in imports and smaller falls in exports. These effects are comparatively small in Australasia because it is a major exporter to Asia of natural resource based goods whose prices fall substantially. Overall, Australasia's terms of trade gain relative to developing Asia is therefore smaller and hence it suffers a terms of trade loss and a real depreciation relative to Europe and the United States.

Although the exogenous output contractions in developing Asia and Japan are substantial, as indicated in the first two columns of Table 8 , the corresponding changes in other regions' output levels are comparatively small. Clearly, worst hit are the tradeable goods sectors in virtually all the non-Asian regions. The real appreciations experienced

\footnotetext{
${ }^{35}$ The comparatively open US capital market, the expectations associated with it and the sensitivity of investors in the US and abroad to Federal Reserve nominal interest rate settings there are therefore not represented.
} 
relative to Asia have made Asian goods and services comparatively cheap. ${ }^{36}$ Contractions in agriculture and mining in the other regions are primarily associated with the loss of Asian imports, while the contractions in manufacturing are associated with competition from enlarged Asian exports. Overall, however, there are small net enlargements of GDP in the other regions following the expansion of investment there and this expansion is led by their substantial services sectors. Even though savings in the non-Asian regions is a constant proportion of national income and that rises by only a small amount, their private consumption volumes rise more substantially as the real appreciations against developing Asia and Japan see the relative prices of imports fall.

Back in Asia, recall that the output declines result from both changes in investment and insolvencies. Associated with the latter is the idling of capital in the short run. The extent of implied idling of capital due to insolvencies depends, as discussed in Part III, upon associated changes in product prices, wage rates and capital returns in each affected sector. These changes are shown in Table 9. In some sectors, particularly mining and labour intensive manufacturing in developing Asia and skill-intensive manufacturing in Japan, the contractions in production are very much larger than can be explained by reduced investment alone. Indeed they are so large that the product price rises, suggesting that firms in the sectors would now be viable but for a high level of indebtedness and hence vulnerability to crisis type shocks. The substantial output reductions therefore imply a high rate of capital idling which confers rents on the owners of the remaining sector specific capital.

The overall pattern of changes in unit factor rewards is indicated in Table 10. Most striking are the declines in the returns to land and natural resources worldwide. This is because the now recessed Asian economies are major importers of agricultural and resource based goods. The returns to capital rise worldwide as capital is idled in Asia. ${ }^{37}$ Turning to labour and skill, we do not see the anticipated difference in the effects on these factor markets. They are similarly affected in each region. There is, however, a stark dichotomy between labour reward changes in Asian and other regions. Labour, skill, land and resources are big losers in Asia while the principal gainers are labour and skill in the other regions. Clearly, the dominant change is the redistribution of investment across regions. Even though this has no

\footnotetext{
${ }^{36}$ The real appreciations relative to Japan are particularly large, and possibly unrealistically so given that macroeconomic policy in North America and Europe, the effects of which are not represented here, has been directed at forestalling such large changes in the short run.
} 
impact on the productive capital stock at the lengths of run simulated here, it affects both the demand for capital goods at the regional level and the real exchange rate. The former raises regional labour demand but the latter reduces competitiveness in tradeable goods sectors. Since most employment is in little traded services, and since the services sector in the north is ultimately the major beneficiary of the investment redistribution, there is a net increase in both labour and skill demand in the northern regions.

Even so, the effects on labour and skill in the north are surprisingly similar. Superficially, one would expect inferior labour market performance from low skill labour since its traditional employers have been in agriculture and manufacturing and these sectors contract and shed workers in the short run. Northern manufacturing suffers, however, both at the labour and the skill intensive ends, since net manufactured exports rise in Japan and developing Asia and because of the associated northern real appreciations. In northern labour markets, the main counterbalancing force is the expansion of services and particularly the labour intensive services sector. Demand growth there is sufficient to raise the real unit rewards of unskilled workers throughout the economy in each region.

Turning to the medium run, we presume that production shortfalls due to insolvency are resolved but that developing Asia and Japan have investment that remains at the same reduced level as in the short run. At the same time, any recovery in output raises (now fixed rate) saving and further enhances their capital account deficits. This pattern is evident from the balance of payments details given in Table 11. The capital account imbalances of both developing Asia and Japan are larger than before by 35 per cent, while the increase in regional saving is three to five times larger. These changes are offset mainly by more substantial increases in exports than before. Exports are eight fold larger for developing Asia and 60 per cent larger in the case of Japan. The associated real appreciations are larger than in the short run relative to developing Asia but little changed relative to Japan. This change is largest for Australasia whose terms of trade improvement is bolstered by the input demand effect of increased production in Asian trading partners. "Expected" returns to capital in Australasia are higher and so the proportional increase in investment there is greater than for the other regions. This enlarges its real appreciation relative to developing Asia.

\footnotetext{
${ }^{37}$ Recall that capital remains industry specific in these solutions and the numbers shown are changes in total regional returns.
} 
Without the idling of capital due to insolvency, overall output contractions are more modest than before, as indicated in Table 12. The predominant Asian contractions are in the labour intensive services sector. And these are offset in part by substantial expansions in the export-manufacturing sector in each case. In developing Asia, it is labour intensive manufacturing that expands while the skill-intensive manufacturing sector expands in Japan. In essence, whereas the short run saw declines in their levels of manufacturing production, in the medium run these two regions pump out their manufactured exports at rates above the pre-recession period.

In the other regions the general pattern is similar to that of the short run results. The contractions in manufacturing and the offsetting expansions in labour intensive services are amplified, however. In the north, the contractions occur mainly in skill-intensive manufacturing. Once again, therefore, the effects on employment in the north can be expected to be offsetting. The overall pattern of changes in unit factor rewards is laid out in Table 13. Even though Asian output shocks are smaller in the medium run, the effects on real unit factor rewards are similar to the short run. Land and resources continue to be the principal losers in the north and labour and skill enjoy real gains that, while still small, are nonetheless larger than the changes in the short run.

If recovery in Asia can be thought of as the reverse of the shocks administered here, it will clearly hurt workers in the north and benefit workers in Asia. Yet previous analyses applying the same analytical framework to the long boom in Asia have found that Asian growth combined with expanded trade with the north was, in and of itself, beneficial to northern workers, and even to the unskilled. ${ }^{38}$ The key difference here is that the Asian recession is a short run phenomenon. Its dominant characteristic is the redistribution of investment across regions and the pattern of real appreciations that this creates. By comparison, the long boom in Asia was sufficiently gradual that changes in external balance were of minor significance. Nonetheless, the long boom did cheapen the north's imports and raise global demand for its exports. The gains from this terms of trade improvement raised northern income and "trickled down" to unskilled workers principally through expansion of the labour intensive services sector. By contrast, in the short run the reverse of the Asian recession shocks would substantially contract northern investment and hence aggregate 
demand in the north. Services sectors in the north would therefore contract, reducing labour demand.

Yet the Asian recovery is not simply a reverse of the Asian recession. For one thing, the rate of capital accumulation in the north has been higher during the Asian recession while that in Asia has been lower. So long as some of this over-trend investment in the north has been in the tradeable goods sectors, Asian firms will find that the recovery sees not only their real exchange rates shifting unfavourably but also that the competition abroad has acquired a technological advantage. ${ }^{39}$

\section{Conclusion}

Superficially, one might think of the Asian recession as the reverse of the long Asian boom that preceded it. Much has been said about how this boom was export driven and how the exports caused substantial structural change in the north, shifting the demand for labour toward increased skill and, finally, about how this hurt northern low-skill workers. Although new research has cast doubt on this thesis ${ }^{40}$, it remains of interest to ask whether low skill workers might indeed be advantaged by the Asian demise. Even though our own results, derived using the same type of analysis as used here, tended to contradict the long boom thesis, we now find that the Asian demise does appear to advantage workers in the North. Moreover, it advantages all northern workers, both skilled and unskilled, by similar proportions.

In the short run imbalances between investment and saving at the regional level are important. The sharp decline in investment in Asia, combined with increased saving substantially raises investment in other regions, and particularly the US and the EU. The associated rise in the demand for capital goods there stimulates the northern economies, raising overall labour demand. Against this, however, are substantial real appreciations relative to developing Asia and Japan. These reduce the competitiveness of the northern tradeable goods sectors and tend to contract employment, particularly in agriculture and manufacturing. But the effect of enhanced investment spending (the capital account effect

\footnotetext{
${ }^{38}$ See Tyers and Yang (1997 and 1999a). In these studies, as here, labour and skill are separated in broad groups. More disaggregation would clearly have uncovered at least some low-skill workers who would have been disadvantaged by the long boom in Asia.

${ }^{39}$ For an analysis of this issue, see Tyers and Yang (1999b).

${ }^{40}$ See, for example, the recent survey by Tyers et al. (1999a).
} 
discussed earlier) is dominant, and particularly in the labour-intensive services sector. Overall, there is a net increase in the demand for both labour and skill in the northern regions.

Unlike the long boom in reverse, the Asian recession extends to Japan, a larger economy than that of developing Asia, and one specialised in skill-intensive goods. This tends to offset any bias in favour of northern high-skill workers. The recessed Asian economies do expand exports, but this expansion is largely labour intensive from developing Asia and skill intensive from Japan. In the end, it is the expansion in the services sectors of the northern economies that determines the distribution of real wage effects.

Also unlike the long boom in reverse, the shocks associated with the Asian recession are short run in nature and readily reversible. Superficially, we are implying that the Asian recovery, if it reverses the shocks of the recession, must hurt northern workers. Whether this turns out to be true depends on two matters that go beyond the scope of this study. First, short run shocks such as those simulated here are substantially affected by macroeconomic policy. Monetary policy, appropriately coordinated in the north, can and probably has helped mitigate the sudden changes in the real exchange rate that are so important in the foregoing analysis. Second, the new investment now taking place in the north will affect the postrecession pattern of production costs. If, as a consequence, the north enjoys a productivity gain relative to Asia, the Asian recovery will not fully reverse the shocks considered here.

\section{References:}

Adams, P.D., "Computable general equilibrium analysis of the consequences for Australia of the Asian crisis", Centre of Policy Studies, Monash University, 1998.

Bayoumi, T. and C. Towe, "Macroeconomic developments and prospects", in IMF, Selected Issues, Staff Country Report, Washington DC: July 1998.

Bhagwati, J. and M.H. Kosters, Trade and Wages: Leveling Wages Down?, Washington DC: AEI Press, 1994.

Bontout, O. and S. Jean, "Wages and unemployment: the impact of trade and technology under different labour market paradigms", Research Paper 99/6, Centre for Research on Globalisation and Labour Markets, School of Economics, University of Nottingham, 1999.

Burfisher, M.E., S. Robinson and K.E. Thierfelder, "Wage Changes in a U.S.-Mexico Free Trade Area: Migration versus Stolper-Samuelson Effects", In J.F. Francois and C.R. Shiells, eds. Modeling trade policy: Applied general equilibrium assessments in North American free trade. Cambridge; New York and Melbourne: Cambridge University Press, 1994, pp 195-222.

Burtless, G., "International trade and the rise in earnings inequality", Journal of Economic Literature XXXIII: 800-816, June 1995. 
Cooper, R., "Is growth in developing countries beneficial to industrial countries?

Bruno and B. Pleskovic, Annual World Bank Conference on Development Economics 1995, World Bank, Washington DC, 1996.

Corbett, J. and D. Vines, "Asian currency and financial crises: Lessons from vulnerability,

The World Economy, forthcoming, March 1999.

,"The Asian Crisis: lessons from the collapse of financial systems, exchange rates and macroeconomic policy", Chapter 2 in R. Agenor, M. Miller, D. Vines and A. Weber (eds.) The Asian Financial Crisis: Causes, Contagion and Consequences, Cambridge: Cambridge University Press, forthcoming 1999.

Corsetti, G., P. Pesenti and N. Roubini, "What caused the Asian currency and financial crisis?", Department of Economics, New York University, March 1998.

Engel, C.M., "Exchange rates and prices", NBER Reporter, Winter 1998-99, pp 13-17, Cambridge Massachusetts: National Bureau of Economic Research, 1999.

Falvey, R., R. Tyers and R. McDougall, "Trade shocks and the magnitude of transmitted wage adjustments", Working Papers in Economics and Econometrics No. 318, Faculty of Economics and Commerce, Australian National University, February 1997.

Freeman, R.B., "Are your wages set in Beijing? Journal of Economic Perspectives, 9(3): 1532, Summer 1995.

Francois, J.F. and D. Nelson, "Trade, technology and wages: general equilibrium mechanics", Economic Journal, 108 (September): 1483-1499, 1988.

Goldstein, M., The Asian Financial Crisis: Causes, Cures and Systemic Implications, Policy Analysis in International Economics No.55, Institute for International Economics, Washington, DC, June 1998.

Hertel, T.W. (ed.), Global Trade Analysis Using the GTAP Model, New York: Cambridge University Press, 1997.

Hertel, T.W. and M. Tsigas,, "Structure of GTAP”, Chapter 2 in T.W. Hertel (ed.), op cit. 1997.

Horiuchi, A., "Japan". Chapter 12 in McLeod, R. and R. Garnaut (eds.) op cit.

Huff, K.M., K. Hanslow, T.W. Hertel and M.E. Tsigas, "GTAP behavioural parameters", Chapter 4 in T.W. Hertel (ed.) op cit 1997.

IMF, World Economic Outlook, International Monetary Fund, Washington DC, October 1998.

IMF, World Economic Outlook, International Monetary Fund, Washington DC, May 1999.

Krugman, P., "Growing world trade: causes and consequences", Brookings Papers on Economic Activity, 1:327-377, 1995.

Lane, T., A.R. Ghosh, J. Hamann, S. Phillips, M. Schulze-Ghattas and T. Tsikata, "IMFsupported programs in Indonesia, Korea and Thailand: a preliminary assessment". IMF, Washington DC, Jan 1999.

McDougall, R.A., A. Elbehri and T.P. Truong (eds.) Global Trade, Assistance and Protection: The GTAP 4 Database, Center for Global Trade Analysis, Purdue University, December 1998a.

Makin, A., "The great East Asian capital flow reversal: reasons, responses and ramifications", The World Economy, 22(3): 407-419, 1999.

McDougall, R.A., B. Dimaranan and T.W. Hertel, "Behavioural parameters". Chapter 19 in R.A. McDougall, A. Elbehri and T.P. Truong (eds.) Global Trade, Assistance and Protection: The GTAP 4 Database, Center for Global Trade Analysis, Purdue University, December 1998b. 
McKibbin, W.J., "The crisis in Asia: an empirical assessment", Brookings Discussion Paper in International Economics 136, Washington DC: The Brookings Institution, 1998a. , "Internationally mobile capital and the global economy", Chapter 14 in McLeod and Garnaut (eds.) op cit pp 227-244, 1998b.

McKibbin, W.J. and W. Martin, "The East Asian crisis: investigating causes and policy mimeo, World Bank and the Australian National University, 1998.

McLeod, R.H. and R. Garnaut (eds.), East Asia in Crisis: from being a miracle to needing one, London: Routledge 1998.

Minford, P., J. Riley and E. Nowell, 'Trade, technology and labour markets in the world economy, 1970-1990: a computable general equilibrium analysis', Journal of Development Studies, 34(2): 1-34, December 1997.

Noland, M., L. Liu, S. Robinson and Z. Wang, Global Effects of the Asian Currency Devaluations, Policy Analysis in International Economics No.56, Institute for International Economics, Washington, DC, July 1998.

Radelet, S. and J. Sachs, "The onset of the East Asian financial crisis", Harvard Institute for International Development, February 1998.

Richardson, J.D., "Income inequality and trade: how to think, what to conclude", Journal of Economic Perspectives 9(3): 33-56, Summer 1995.

Suryahadi, A.Y., "The effects of openness on developing country labour markets: the case of Indonesia", doctoral dissertation, Australian National University, December 1998.

Tyers, R., "Sectoral similarity and the magnitude of Stolper-Samuelson Effects", Working Papers in Economics and Econometrics, Australian National University, Canberra, July 1999.

Tyers, R., R. Duncan and W. Martin, “Trade, Technology and Labor Markets: General Journal of Economic Integration, 14(2), forthcoming 1999. , "Trade and wages: integrating theory and numerical analysis", in J. Francois and D. van der Mensbrugghe (Eds.) Globalisation and Employment Patterns: Policy, Theory and Evidence, OECD, 1999.

Tyers, R. and Y. Yang, "Trade with Asia and skill upgrading: effects on labor markets in the Weltwirtshaftliches Archiv, Band 133, Heft 3, September 1997, pp 383-418.

, "European unemployment and the Asian emergence", Working Papers in Economics and Econometrics No.369, Australian National University, Canberra, March 1999a.

, "The global impact of capital flow redirection: an application to the Asian recovery", Working Papers in Economics and Econometrics, Australian National University, Canberra, July 1999b.

Wong, K.Y. (ed.), "The Asian crisis: what has happened and why? Economics, University of Washington, Seattle, August 1998.

Wood, A., North-South Trade, Employment and Inequality, Clarendon Press, Oxford 1994.

World Bank, "The crisis pictured", Asiaweek, April 16, 1999, as presented on the web site: www.pathfinder.com/asiaweek/99/0416/cs3a_crisis.html. 
Table 1: Model analytics:

Single household in each region.

Utility Cobb-Douglas in:

private household expenditure

government expenditure

savings (share and marginal propensity can be modified exogenously)

Government consumption: Cobb-Douglas composite of all goods.

Private household consumption: $\mathrm{CDE}^{\mathrm{a}}$ expenditure function.

Decomposition between home goods and imports: Armington.

Decomposition of imports by region of origin: Armington.

Firms are perfectly competitive with constant returns to scale.

Technology is a Leontief combination of intermediate inputs

with a CES composite of primary factors.

Intermediate demand is decomposed to home goods and imports as for household

final consumption.

Primary factor demand is split according to the nested CES system in Figure 1.

Land and natural resources are specific to agriculture and mining, respectively.

All other factors are perfectly mobile between industries.

Primary factor supply: all factors are inelastic in supply. ${ }^{\mathrm{b}}$

Capital returns are intra-regional.

Investment: worldwide is the sum across regions' savings.

Where investment is endogenous, it is allocated across regions so that the proportional change in investment is larger in regions with high rates of return on capital. This equalises "expected return".

Investment does not affect the current productive capital stock but it does consume capital goods and its pattern of regional allocation has a significant influence on the capital account of each region's balance of payments, and hence on the real exchange rate.

\footnotetext{
a Constant Difference of Elasticities. See Huff et al. (1997: 133-147).

b Households can transform labour between skilled and unskilled. However, this capability is reduced to negligibility in the applications discussed in this paper.

c The formulation of expected returns, along with some alternative investment allocation rules, is discussed in Hertel and Tsigas (1997: 54-60).
} 


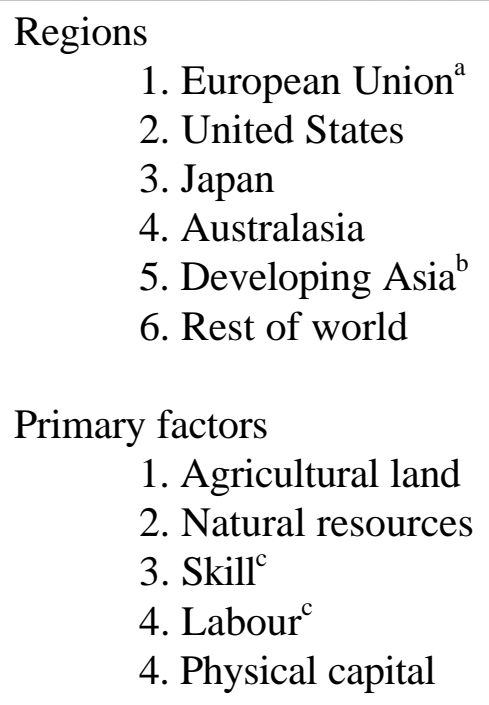

\section{Sectors}

Full 50 goods and services defined in the GTAP database. Aggregated to eight after model solutions, for ease of presentation only. The six aggregates are:

1. Agriculture

2. Mining and energy

3. Skill-intensive manufacturing

4. Labour-intensive manufacturing

5. Skill-intensive services

6. Labour-intensive services

a The European Union of 15.

b China, including Hong Kong and Taiwan, Korea (Rep.), Indonesia, Philippines, Malaysia, Singapore, Thailand, Vietnam.

c The labour disaggregation is based on the ILO Classification of Occupations. Professional workers are defined as including managers and administrators, professionals and para-professionals. Production workers are plant and machine operators and drivers, tradespersons, clerks, labourers and related workers, salespersons and personal service workers. 
Table 3: Factor proportions in the EU, per cent ${ }^{\mathrm{a}}$

\begin{tabular}{lrrrrrrr}
\hline Sector & $\begin{array}{c}\text { Share of } \\
\text { GDP }\end{array}$ & Land & Labour & Skill & Capital & $\begin{array}{c}\text { Nat. } \\
\text { Rescs }\end{array}$ & Total \\
\hline Agriculture & 3 & $10(7)$ & $58(53)$ & $4(11)$ & $24(26)$ & $4(3)$ & 100 \\
Mining & 1 & $0(0)$ & $17(24)$ & $9(14)$ & $38(37)$ & $36(25)$ & 100 \\
Manuf. labour intensive & 7 & $0(1)$ & $57(50)$ & $20(21)$ & $23(27)$ & $0(1)$ & 100 \\
$\quad$ skill intensive & 18 & $0(0)$ & $48(45)$ & $26(26)$ & $26(29)$ & $0(0)$ & 100 \\
Services: labour intensive & 32 & $0(0)$ & $41(41)$ & $17(20)$ & $42(39)$ & $0(0)$ & 100 \\
$\quad$ skill intensive & 39 & $0(0)$ & $34(36)$ & $36(33)$ & $30(31)$ & $0(0)$ & 100 \\
\hline
\end{tabular}

a Listed are value added shares with, in parentheses, total factor proportions (including the factor content of intermediate inputs).

Source: GTAP Database Version 4.1. See McDougall et al. (1998a).

Table 4: Elasticities of substitution in intermediate and primary factor demand ${ }^{\mathrm{a}}$

\begin{tabular}{|c|c|c|c|}
\hline Sector & $\begin{array}{l}\text { In product } \\
\text { demand, } \\
\text { between } \\
\text { domestic and } \\
\text { imported }\end{array}$ & $\begin{array}{l}\text { In import } \\
\text { demand, } \\
\text { between regions } \\
\text { of origin }\end{array}$ & $\begin{array}{l}\text { In factor } \\
\text { demand, } \\
\text { between } \\
\text { primary factor } \\
\text { groups }\end{array}$ \\
\hline Agriculture & 2.5 & 4.6 & 0.2 \\
\hline Mining & 2.8 & 5.6 & 0.2 \\
\hline Manufacturing: labour intensive & 2.8 & 6.0 & 1.2 \\
\hline \multirow{3}{*}{ Services: } & 2.8 & 5.9 & 1.2 \\
\hline & 2.0 & 3.8 & 1.5 \\
\hline & 1.9 & 3.8 & 1.3 \\
\hline
\end{tabular}

a These are group-specific weighted averages across the 50 industries defined in the database. The structure of intermediate and primary factor demand is indicated in Figure 1. The CDE parameters governing substitution in final demand are discussed in McDougall et al. (1998b). Substitution elasticities in intermediate product demand, and between intermediates and primary factors, are set to unity (Cobb-Douglas) in this analysis.

b The complete set of GTAP factor substitution elasticities are listed in Table 19.2 of McDougall et al. (1998). The elasticity of substitution within the labour group, between skilled and unskilled labour, is set at unity. Households' corresponding elasticity of transformation between skilled and unskilled labour is set to negligibility for this analysis.

Source: GTAP Database Version 4.1. See McDougall et al. (1998a). 
Table 5 Short run shocks and closure ${ }^{\mathrm{a}}$

\section{Developing Asia:}

Regional investment as a proportion of GDP is made exogenous and reduced by $7 \%$.

Trade balance (X-M) is made exogenous and increased by US\$ 155 billion, while the average regional saving rate is made endogenous ${ }^{\mathrm{b}}$.

Production volume by sector is made exogenous and reduced as indicated in Table 8 , while sectoral capital use is made endogenous.

Labour productivity in agriculture is reduced ${ }^{\mathrm{c}}$ by $5 \%$ and land productivity increased by $2 \%$.

Labour (skilled and unskilled) remains sectorally mobile and is fully employed.

Japan:

Regional investment is made exogenous and reduced by $10 \%$.

Trade balance (X-M) is made exogenous and increased by US\$ 216 billion, while the average regional saving rate is made endogenous ${ }^{\mathrm{b}}$.

Production volume by sector is made exogenous and reduced as indicated in Table 8 , while sectoral capital use is made endogenous.

Labour (skilled and unskilled) remains sectorally mobile and is fully employed.

\section{EU, Australasia:}

Regional investment is endogenous to equalise regional average "expected returns" across EU, US, Australasia and the rest of the world. ${ }^{\mathrm{d}}$

The trade balance is endogenous, while the average savings rate is retained exogenous.

Sectoral production volumes are endogenous, while sectoral capital use is exogenous.

Labour (skilled and unskilled) remains sectorally mobile and the real wage of raw labour is flexible upward only.

\section{US and rest of world:}

Regional investment is endogenous to equalise regional average "expected returns" across EU, US, Australasia and the rest of the world. ${ }^{\mathrm{d}}$

The trade balance is endogenous, while the average savings rate is retained exogenous.

Sectoral production volumes are endogenous, while sectoral capital use is exogenous.

Labour (skilled and unskilled) remains sectorally mobile and both real wages are flexible.

a In both the short and medium run, capital is completely sector specific in all regions, so that the rate of return differs across sectors.

b Since the capital account and current account must be equal in magnitude and opposite in sign, $\mathrm{I}-\mathrm{S}=\mathrm{M}-\mathrm{X}$. For both developing Asia and Japan, this implies a contraction in investment and a rise in saving (and hence a movement toward deficit on the capital account) which is balanced by a fall in imports relative to exports (a movement toward surplus on the current account).

c This implies a reduction in the number of effective labour units supplied per worker.

d See Table 1 for further explanation.

e In the end, this constraint does not bind since both real wages rise.

Source: IMF (1998, 1999), web sites of Statistics Indonesia and Ministry of International Trade and Industry (MITI) Japan, 1997-98 changes. For countries in the developing Asia for which no sectoral production data is yet available, short run output contractions have the same sectoral distribution as those in Indonesia while the magnitudes are adjusted in proportion to the size of their associated GDP contractions. 
Table 6 Medium run shocks and closure ${ }^{\mathrm{a}}$

\section{Developing Asia:}

Regional investment is made exogenous and reduced by the proportion implied in the short run solution ( $I$ is held constant at its short run level).

The average regional saving rate is now made exogenous at the value achieved in the short run solution. ${ }^{\mathrm{b}}$ The trade balance (X-M) is now made endogenous.

Sectoral production volumes are endogenous, while sectoral capital use is exogenous.

Labour and land productivity in agriculture are restored to reference levels.

Labour (skilled and unskilled) remains sectorally mobile and is fully employed.

\section{Japan:}

Regional investment is made exogenous and reduced by the proportion implied in the short run solution ( $I$ is held constant at its short run level).

The average regional saving rate is now made exogenous at the value achieved in the short run solution. ${ }^{\mathrm{b}}$ The trade balance $(\mathrm{X}-\mathrm{M})$ is now made endogenous.

Sectoral production volumes are endogenous, while sectoral capital use is exogenous.

Labour (skilled and unskilled) remains sectorally mobile and is fully employed.

\section{EU, Australasia:}

Regional investment is endogenous to equalise regional average "expected returns" across EU, US, Australasia and the rest of the world. ${ }^{\circ}$

The trade balance is endogenous, while the average savings rate is retained exogenous. Sectoral production volumes are endogenous, while sectoral capital use is exogenous.

Labour (skilled and unskilled) remains sectorally mobile and the real wage of raw labour is flexible upward only. ${ }^{\mathrm{e}}$

\section{US and rest of world:}

Regional investment is endogenous to equalise regional average "expected returns" across EU, US, Australasia and the rest of the world. ${ }^{\mathrm{c}}$

The trade balance is endogenous, while the average savings rate is retained exogenous.

Sectoral production volumes are endogenous, while sectoral capital use is exogenous.

Labour (skilled and unskilled) remains sectorally mobile and both real wages are flexible.

a In both the short and medium run, capital is completely sector specific in all regions, so that the rate of return differs across sectors.

b Since the capital account and current account must be equal in magnitude and opposite in sign, $\mathrm{I}-\mathrm{S}=\mathrm{M}-\mathrm{X}$. For both developing Asia and Japan, these changes impose explicit contractions in investment and rises in the average rate of saving, balanced by a now endogenous rise in exports relative to imports.

c See Table 1 for further explanation.

e In the end, this constraint does not bind since both real wages rise.

Source: IMF $(1998,1999)$, web site of Statistics Indonesia and that of MITI in Japan, 1997-98 changes. 
Table 7: Short run changes in the balance of payments and real exchange rate following the recession in developing Asia and Japan, 1995 US\$ billion $^{\mathrm{a}}$

\begin{tabular}{|c|c|c|c|c|c|c|}
\hline Sector & $\begin{array}{l}\text { Dev. } \\
\text { Asia }\end{array}$ & Japan $^{\text {b }}$ & USA & EU & $\begin{array}{c}\text { Austra- } \\
\text { lasia }\end{array}$ & $\begin{array}{c}\text { Rest of } \\
\text { world }\end{array}$ \\
\hline Capital account surplus (I-S) & -155 & -216 & 109 & 163 & 7 & 91 \\
\hline Investment, I & -135 & -203 & 123 & 185 & 7 & 103 \\
\hline Saving, $S$ & 20 & 13 & 14 & 22 & 0 & 12 \\
\hline Current account deficit (M-X) & -155 & -216 & 109 & 163 & 7 & 91 \\
\hline Imports, $\mathrm{M}$ & -142 & -95 & 63 & 124 & 2 & 58 \\
\hline Exports, $\mathrm{X}$ & 13 & 121 & -46 & -40 & -5 & -33 \\
\hline \multicolumn{7}{|l|}{ Relative to developing Asia } \\
\hline Real appreciation ${ }^{\mathrm{b}}, \%$ & 0 & -5.4 & 8.5 & 8.9 & 5.5 & 8.0 \\
\hline Terms of trade change ${ }^{\mathrm{c}}, \%$ & 0 & -4.9 & 3.4 & 2.1 & .8 & 1.5 \\
\hline
\end{tabular}

a Short run closure details are indicated in Table 5.

b Here the change in the real exchange rate is approximated by the per cent change in the ratio of the region's GDP deflator with that of developing Asia.

c Change in the value of exports at endogenous prices, weighted by fixed 1995 (base period) export volumes, divided by the value of exports, weighted by fixed 1995 import volumes.

Source: Model simulations described in the text.

Table 8: Short run changes in gross sectoral output and GDP following the recession in developing Asia and Japan, per cent ${ }^{\mathrm{a}}$

\begin{tabular}{|c|c|c|c|c|c|c|}
\hline Sector & $\begin{array}{l}\text { Dev. } \\
\text { Asia }\end{array}$ & Japan $^{\text {b }}$ & USA & EU & $\begin{array}{c}\text { Austra- } \\
\text { lasia }\end{array}$ & $\begin{array}{c}\text { Rest of } \\
\text { world }\end{array}$ \\
\hline Agriculture & -4.1 & -2.0 & -1.5 & -1.0 & -2.1 & -0.4 \\
\hline Mining & -10.9 & -2.7 & -0.3 & -0.7 & -0.5 & -0.6 \\
\hline Manufacturing: & -4.9 & -4.9 & -0.3 & -0.1 & -0.1 & -0.2 \\
\hline skill intensive & -9.6 & -1.9 & -0.3 & -0.6 & 1.1 & 0.3 \\
\hline Services: & -9.3 & -5.4 & 1.2 & 1.4 & 0.7 & 1.4 \\
\hline skill intensive & -11.1 & -6.2 & 0.1 & 0.1 & -0.1 & 0.0 \\
\hline GDP & -8.5 & -4.9 & 0.1 & 0.1 & 0.1 & 0.2 \\
\hline
\end{tabular}

a Short run closure details are indicated in Table 5.

b Sectoral production changes in developing Asia and Japan are exogenous.

Source: Model simulations described in the text. 
Table 9: Short run changes in product prices, capital returns and capital utilisation in developing Asia and Japan, per cent ${ }^{\mathrm{a}}$

\begin{tabular}{lccccccc}
\hline & \multicolumn{3}{c}{ Developing Asia } & \multicolumn{3}{c}{ Japan } \\
\hline Sector & Price $^{\mathrm{b}}$ & $\begin{array}{l}\text { Capital } \\
\text { return }^{\mathrm{c}}\end{array}$ & $\begin{array}{l}\text { Capital } \\
\text { use }\end{array}$ & Price $^{\mathrm{b}}$ & $\begin{array}{l}\text { Capital }^{\mathrm{c}} \\
\text { return }^{\mathrm{c}}\end{array}$ & $\begin{array}{l}\text { Capital } \\
\text { use }\end{array}$ \\
\hline Agriculture & -6 & -13 & 0 & -3 & -5 & 0 \\
Mining & 5 & 62 & -19 & 2 & 27 & -9 \\
Manufacturing: & labour intensive & 3 & 24 & -23 & 2 & 17 & -19 \\
\multirow{3}{*}{ Services: } & skill intensive & 4 & 18 & -2 & 4 & 26 & -22 \\
& labour intensive & -2 & -5 & -7 & -1 & -1 & -8 \\
& skill intensive & 2 & 12 & -21 & -1 & -1 & -7 \\
\hline
\end{tabular}

a Short run closure details are indicated in Table 5.

$\mathrm{b} \quad$ Producer price relative to the region's GDP deflator.

c Unit reward of capital relative to the region's GDP deflator.

Source: Model simulations described in the text.

Table 10: Short run changes in real factor rewards, per cent ${ }^{\mathrm{a}}$

\begin{tabular}{lcccccc}
\hline Primary factor & $\begin{array}{c}\text { Dev. } \\
\text { Asia }\end{array}$ & Japan & USA & EU & $\begin{array}{c}\text { Austra- } \\
\text { lasia }\end{array}$ & $\begin{array}{c}\text { Rest of } \\
\text { world }\end{array}$ \\
\hline Labour & -5.1 & -3.5 & 0.6 & 0.5 & 0.5 & 0.8 \\
Skill & -6.5 & -3.6 & 0.4 & 0.5 & 0.3 & 0.6 \\
Capital $^{\text {b }}$ & 8.5 & 6.1 & 0.3 & 0.5 & 0.1 & 0.2 \\
Land $_{\text {Natural resources }}$ & -16.1 & -4.9 & -5.0 & -4.3 & -6.2 & -1.7 \\
\hline
\end{tabular}

a Short run closure details are indicated in Table 5. All entries are unit rewards relative to the region's consumer price index.

b Capital is sector specific and hence has returns that differ by sector. Here the change in the region's total reward of capital is given.

Source: Model simulations described in the text. 
Table 11: Medium run changes in the balance of payments and the real exchange rate following the recession in developing Asia and Japan, 1995 US\$ billion ${ }^{\mathrm{a}}$

\begin{tabular}{|c|c|c|c|c|c|c|}
\hline Sector & $\begin{array}{l}\text { Dev. } \\
\text { Asia }^{b}\end{array}$ & Japan $^{\text {b }}$ & USA & EU & $\begin{array}{c}\text { Austra- } \\
\text { lasia }\end{array}$ & $\begin{array}{c}\text { Rest of } \\
\text { world }\end{array}$ \\
\hline Capital account surplus (I-S) & -209 & -273 & 140 & 210 & 10 & 121 \\
\hline Investment, I & -142 & -207 & 155 & 231 & 11 & 135 \\
\hline Saving, $\mathrm{S}$ & 67 & 66 & 14 & 22 & 1 & 14 \\
\hline Current account deficit (M-X) & -209 & -273 & 140 & 210 & 10 & 121 \\
\hline Imports, $\mathrm{M}$ & -100 & -78 & 83 & 130 & 5 & 69 \\
\hline Exports, $\mathrm{X}$ & 109 & 194 & -57 & -80 & -5 & -52 \\
\hline \multicolumn{7}{|l|}{ Relative to developing Asia } \\
\hline Real appreciation ${ }^{\mathrm{b}}, \%$ & 0 & -3.7 & 9.7 & 10.0 & 8.1 & 9.4 \\
\hline Terms of trade change ${ }^{c}, \%$ & 0 & -5.6 & 5.8 & 3.5 & 3.9 & 3.3 \\
\hline
\end{tabular}

a Short run closure details are indicated in Table 5.

b Here the change in the real exchange rate is approximated by the per cent change in the ratio of the region's GDP deflator with that of developing Asia.

c Change in the value of exports at endogenous prices, weighted by fixed 1995 (base period) export volumes, divided by the value of exports, weighted by fixed 1995 import volumes.

Source: Model simulations described in the text.

Table 12: Medium run changes in gross sectoral output and GDP following the recession in developing Asia and Japan, per cent ${ }^{\mathrm{a}}$

\begin{tabular}{|c|c|c|c|c|c|c|}
\hline Sector & $\begin{array}{l}\text { Dev. } \\
\text { Asia }\end{array}$ & Japan & USA & EU & $\begin{array}{c}\text { Austra- } \\
\text { lasia }\end{array}$ & $\begin{array}{c}\text { Rest of } \\
\text { world }\end{array}$ \\
\hline Agriculture & -1.6 & -1.0 & -1.1 & -0.7 & -1.9 & -0.2 \\
\hline Mining & 0.7 & 0.4 & -0.2 & -0.6 & -0.8 & -0.5 \\
\hline Manufacturing: & 5.1 & -0.6 & -0.6 & -0.4 & -0.8 & -0.7 \\
\hline skill intensive & 1.8 & 5.9 & -1.2 & -1.7 & -0.3 & -0.5 \\
\hline \multirow{2}{*}{ Services: } & -5.2 & -3.4 & 1.6 & 2.1 & 1.6 & 2.2 \\
\hline & -1.5 & -1.7 & 0.2 & 0.2 & 0.2 & 0.1 \\
\hline GDP & -0.6 & -0.1 & 0.1 & 0.2 & 0.3 & 0.4 \\
\hline
\end{tabular}

a Medium run closure details are indicated in Table 6.

Source: Model simulations described in the text. 
Table 13: Medium run changes in real factor rewards, per cent ${ }^{\mathrm{a}}$

\begin{tabular}{lcccccc}
\hline Primary factor & $\begin{array}{c}\text { Dev. } \\
\text { Asia }\end{array}$ & Japan & USA & EU & $\begin{array}{c}\text { Austra- } \\
\text { lasia }\end{array}$ & $\begin{array}{c}\text { Rest of } \\
\text { world }\end{array}$ \\
\hline Labour & -1.0 & -0.7 & 0.7 & 0.6 & 1.0 & 1.0 \\
Skill & -0.9 & -0.9 & 0.4 & 0.5 & 0.8 & 0.8 \\
Capital $^{\mathrm{b}}$ & -0.7 & -0.3 & 0.4 & 0.6 & 0.5 & 0.4 \\
Land $_{\text {Natural resources }}$ & -4.0 & -1.9 & -3.6 & -3.0 & -5.8 & -1.1 \\
\hline
\end{tabular}

a Medium run closure details are indicated in Table 6. All entries are unit rewards relative to the region's consumer price index.

b Capital is sector specific and hence has returns that differ by sector. Here the change in the region's total reward of capital is given.

Source: Model simulations described in the text. 